\title{
The Reform and Practice of Applied Talent Cultivation in Newly Built Undergraduate Universities-Taking Zhejiang Shuren University as an Example
}

\author{
Jin Jinbiao \\ Scientific Research Department of Zhejiang Shuren University
}

\begin{abstract}
As a hot topic in the current education field, applied talent cultivation is also an inevitable trend in the development of newly built undergraduate universities. Under the guidance of the orientation of "teaching service-oriented university", Zhejiang Shuren University, through the reform of "three-three system" talent cultivation mode, has conducted a beneficial exploration on the reform of applied talent cultivation in newly built undergraduate universities, and this should be taken by brother universities as references.
\end{abstract}

Keywords-Newly built undergraduate universities; Applied talents; Cultivation mode

\section{INTRODUCTION}

Since the big increase of enrollment in national colleges and universities, our country has borne above 700 newly built undergraduate universities, and the quantity is about $60 \%$ of common universities nationwide, and it has become an important force for higher education popularization in our country. As per the classification of current talent cultivation layer for universities in our country, most newly built undergraduate universities should focus on cultivating applied talents, and this is not only an important measures to comply with the national talent cultivation strategy adjustment, but also meet the practical demand put forward by the social economy development in local for talent cultivation. It is of practical significance to reinforce the rational reflection on applied talent cultivation.

\section{MAIN PROBLEMS IN THE APPLIED TALENT Cultivation OF NEWLy BuILT UNDERGRADUATE UNIVERSITIES}

Applied talents refers to talents who are engaged in nonacademic research work under the guidance of certain theoretical specification, and the task thereof is to convert abstract theoretical symbol into specific operation conception or product configuration, and apply knowledge into practice. Currently, the cultivation mode of applied talents in undergraduate universities is still largely influenced by traditional talent cultivation mode, and there are mainly several problems as follows:
(1) Most universities have ambiguous positioning, and the disciplines and specialties are detached from the industrial structure in local. Most newly built undergraduate universities don't have obvious local and regional characteristics, and they are engaged in teaching research type or research teaching type school construction, while the school itself doesn't have solid school-running foundation and development conditions, with many development difficulties; the applied talent cultivation objective is relatively generalized; the talent cultivation and regional economic development cannot effectively realize "seamless joint"; the specialty setup and talent cultivation are relatively rigid and traditional; the applied talent cultivation mode is still under the stage of "mudding through", and the homogenization in specialty setup and course system is very serious, which will finally cause the graduates possessing no academic theoretical foundation for research type college graduates, or the practical capacity of higher vocational college graduates, so for them, the way out isn't smooth, and the employment is relatively difficult.

(2)Relatively simple teaching method and mode, and shallow school-enterprise cooperation; many universities "emphasize on theory more than practice" in talent cultivation, with unsound talent cultivation system. In course teaching, problems such as repeating what the book says and the solidified course mode are quite common among teachers, Zhang Dejiang, the Former President for Changchun University of Technology summarized it into five "excessive and insufficient problems": "excessive infusion, insufficient participation; excessive conclusion, and insufficient questions; excessive enclosure, and insufficient divergence expression; excessive emphasis on score, and insufficient emphasis on capacity; excessive written knowledge, and insufficient practical knowledge and the training of problem solving capacity." In the practical teaching, the proportion of practical teaching is generally lower, the base resources inside and outside of the campus are deficient, and there are few opportunities for students to practice, with relatively weak practical capacity; since the overall scientific research of teachers is relatively weak, the capacity for the newly built universities to serve the society is relatively weak, the schoolenterprise cooperation commonly remains at the initial stage, and students are hard to adapt to enterprise demand, the 
enterprises lack in cooperation power, so this has influenced the quality of applied talent cultivation.

(3)The education teaching reform isn't profound enough, with the lack of long-term mechanism construction for applied talents. Due to the school-running history, the leading mechanism, the school-running conditions and other aspects of the newly built undergraduate universities, the cultivation rules for applied talents lack in clear cognition, and some education teaching reforms conducted in schools lack in overall systematicness, and most of them are remaining on the shallow layer, looking "vigorous" superficially, with little effect on talent cultivation. There is one thing that is quite obvious, i.e., there are few cultivation measures of "double-teacher doublecapacity type" teachers, and in the existing title appraisal and employment system, there are few requirements for the practical experience and exercise of teachers, and common teachers relatively lack in the practical experience in the first production line, and cannot provide guidance for teachers considering practice; systematic and professional students' innovation and entrepreneurship guidance are extremely deficient.

Therefore, the only choice for most common undergraduate universities to realize sustainable development is to take the transformation reform as an opportunity, adhere to "facing the local and serving the local", realize "supplementary development, and prominent characteristics", and practically cultivate applied talents meeting the development demand of economic society.

\section{PRACTICAL EXPLORATION ON THE APPLIED TALENT CULTIVATION OF ZHEJIANG SHUREN UNIVERSITY}

As one newly built undergraduate university, Zhejiang Shuren University has clearly put forward the school-running positioning of "teaching service-type university" since 2010; it has adhered to serving teaching, students and the society. Professor Pan Maoyuan held that: "teaching service universities take teaching work as the center, and the applied talent cultivation as the essential task", "the essence of teaching Service University is the undergraduate education of applied technology." The talent cultivation of teaching service type universities is mainly oriented to local economy and social development demand, and it must be closely combined with social economy and industrial development as well as the enterprise production practice, and this can indicate the direction for the cultivation of applied talents. Over the years, the school has initially formed "three-three system" talent cultivation mode, i.e., on the basis of "three-service" demand, conducting "three-field" reform, and constantly deepening applied talent cultivation.

\section{A. Serve regional economy, and optimize professional structure}

Construct professional dynamic adjustment mechanism, and optimize professional structure; in order to closely dock with "seven big trillion industries" in our province, over five years, the school has set 12 specialties (directions), including civil engineering (steel structure direction), environment engineering, investment, pension service, which are in urgent demand for upgrading regional economic industries and improving people's livelihood, and successively adjusted 6 specialties, including refrigeration air conditioner, jewelry identification, and german.

Implement professional applied transformation; the school has formulated and implemented Applied Professional Standards, and as per the requirements of "one specialty docking with one industry (domain)" and "two 30\% and two $60 \%$ ", over five years, it has successively transformed 11 specialties, including Chinese and social work. Currently, the applied specialties in the school has occupied above $85 \%$.

Construct applied professional group; through five years of endeavors, the school has formed seven professional groups, including civil construction, environment engineering, modernized service industry, electronic information, and cultural creativity, and "make the business studies big, the engineering studies special, and the liberal arts active", of which business administration applied specialties were increased by $70 \%$ from $31.6 \%$ in 2005 .

\section{B. Serve employment market, and adjust talent cultivation scheme}

Refine "three-type" applied talent cultivation objective. As per the knowledge application logic relations of "disciplineindustry-profession", start from professional direction and professional angle, conduct refined classification, put forward three basic cultivation objectives, i.e., "composite applied type, field applied type, and professional applied type" for applied talents, put forward the specific specification requirements of talent cultivation from knowledge, capacity and quality, and practiced the direction and route for applied talent cultivation. 
TABLE I.

DESCRIPTION ABOUt THE RELEVANT CHARACTERISTICS OF THREE TyPES OF CULTIVATION OBJECTIVE

\begin{tabular}{|c|c|c|c|c|}
\hline \multicolumn{2}{|c|}{$7_{\text {Contents }}^{\text {Type }}$} & $\begin{array}{l}\text { Comprehensive } \\
\text { Application Type }\end{array}$ & Field Application Type & $\begin{array}{c}\text { Occupational } \\
\text { Application Type }\end{array}$ \\
\hline \multicolumn{2}{|c|}{$\begin{array}{c}\text { Applicable } \\
\text { Professional Category }\end{array}$} & $\begin{array}{c}\text { Management, economy and } \\
\text { trade, humanity, language and } \\
\text { art }\end{array}$ & $\begin{array}{l}\text { Information, civil engineering, } \\
\text { chemical, accounting and } \\
\text { environment engineering }\end{array}$ & $\begin{array}{l}\text { Social work, tourism, } \\
\text { service outsourcing, } \\
\text { and marketing }\end{array}$ \\
\hline \multicolumn{2}{|c|}{$\begin{array}{l}\text { Professional Industry } \\
\text { Subdivision }\end{array}$} & $\begin{array}{l}\text { Focus on major direction, and } \\
\text { partial to major }\end{array}$ & $\begin{array}{l}\text { Focus on major direction, and } \\
\text { partial to occupation }\end{array}$ & $\begin{array}{l}\text { Focus on occupation, } \\
\text { and partial to major } \\
\text { direction }\end{array}$ \\
\hline \multicolumn{2}{|c|}{$\begin{array}{l}\text { Oriented Working } \\
\text { Field (Role) }\end{array}$} & $\begin{array}{c}\text { Small enterprise manager, } \\
\text { chemical trade, and department } \\
\text { manager }\end{array}$ & $\begin{array}{l}\text { Field engineer, monitoring and } \\
\text { maintenance engineer, and project } \\
\text { supervisor }\end{array}$ & $\begin{array}{l}\text { Social worker, tourist, } \\
\text { and marketing operator }\end{array}$ \\
\hline \multirow{3}{*}{$\begin{array}{l}\text { Specificati } \\
\text { on } \\
\text { Requireme } \\
\text { nts }\end{array}$} & $\begin{array}{c}\text { Knowle } \\
\text { dge }\end{array}$ & $\begin{array}{l}\text { Discipline technology and } \\
\text { grafting knowledge }\end{array}$ & $\begin{array}{c}\text { Discipline knowledge, experience } \\
\text { knowledge, and working process } \\
\text { knowledge }\end{array}$ & $\begin{array}{l}\text { Discipline knowledge, } \\
\text { and occupational } \\
\text { knowledge }\end{array}$ \\
\hline & $\begin{array}{c}\text { Capacit } \\
\mathrm{y}\end{array}$ & $\begin{array}{c}\text { Management, trade, language } \\
\text { and other technological } \\
\text { composite capacity }\end{array}$ & Technical application capacity & Post Group skills \\
\hline & Quality & Partial to comprehensive quality & $\begin{array}{l}\text { Basic quality and occupational } \\
\text { quality }\end{array}$ & Occupational belief \\
\hline
\end{tabular}

Implement Course Reform Three-year Action Plan (20092012), and conduct the reform of talent cultivation scheme. The plan takes the construction of course system corresponding to the applied talent cultivation as the core, the teaching method reform and school-enterprise cooperation group construction as the two wings, pays attention to conducting course system construction to promote the combination of course post demand within "platform + module" framework, optimize talent cultivation scheme, and reinforce professional core course construction; improve practical teaching proportion, and that for liberal arts, economic and management types can reach to about $25 \%$, that for science and engineering type can reach to $30 \%$; each specialty will set 1-2 professional modules, open courses oriented to the working process or occupational post, reinforce technical application capacity and occupational capacity cultivation and quality training; pay attention to the teaching method and test method reform,; in the teaching process of each course, adopt above $10 \%$ of credit hours for the discuss learning of teachers and students, and students' course discussion performance at ordinary times will be included into achievement evaluation.

Implement Applied Course Construction Plan. Start from the post demand of employment market, the project group formulates and implements "two $1 / 3$, and two 1/2" applied course evaluation standard, conducts applied transformation for professional main courses, and implement "double certificate" system. Over the recent three years, it has cultivated 53 applied courses, 40 applied textbooks, and above 10 school-enterprise cooperation teams.

\section{Serve production demand, and improve students' application capacity}

Create innovative practice score. From 2010, the school has created 4 innovative practice scores among all undergraduate students, included students' innovation and entrepreneurship, science and technology competition, occupational certificate and other series of innovative practice contents, realize the seamless docking in and outside of the class. Each year, the achievement will pointedly subsidize 100 innovation and entrepreneurship projects, above 20 experiment open projects, strive for above 10 national innovation and entrepreneurship projects, and above 20 provincial "new sprout plan".

Construct industry-university-research experiment (practical training) center. Since 2010, the school has annually input RMB 20,000,000 to construct "computer service outsourcing", "logistics production full-procedure", "largescaled instrument analysis test", "Alibaba service station" and other 11 industry-university-research experiment (practical training) centers and constructed 4 provincial teaching experiment centers. Up till the end of 2015, the total value of teaching equipment in the school has reached up to RMB 170 million.

Promote "diversified" school-enterprise cooperation. The project group uses "diversified" school-enterprise cooperation as the basis, and implements the reform of talent cultivation mode: established above 160 practical bases, of which there are 1 national-level off-campus practical base, and 2 provincial offcampus practical bases; it has also set 45 school-enterprise cooperation virtual classes including "Dongzhong Class", and "Hongshiling Class"; constructed 2 industrial colleges, including "Huawei Network College"; established 23 schoolenterprise cooperated industry-university-research institutions, including "Zhejiang Provincial Housekeeping Talents Cultivation Alliance" and "Zhejiang Provincial Steel Structure 
Talent Cultivation Alliance"; and implemented 3 specialties of "Excellent Engineer Cultivation Plan".

\section{Implement three matching reforms, and ensure applied talent cultivation}

1) Implement course innovation action plan, and conduct the reform of teaching mode and method

Implement "excellent course" creating activities. From 2010, the school has improved "class attendance rate" and "excellent classroom" of students from originally $89 \%$ to the current $95.4 \%$ and $96.3 \%$ through "innovative classroom", "excellent teachers" and "excellent classroom" evaluation, "teaching open month", "speaking lesson competition" and other activities, and the phenomenon of being late is obviously decreased, the quantity of students sleeping and playing mobile phones in class has also been obviously decreased, and it has also effectively aroused the learning enthusiasm of students.

Promote "industrial teachers in classroom, project in classroom, competition in classroom". From 2010, the school has started to implement "thousand industrial teachers" Plan, and annually hired 100 industrial experts to the classroom, and assist in teaching. Currently, 200 "thousand industrial teachers" courses have been established, above 450 industrial leaders are employed to the classroom. The vast teachers have combined the actual cases in enterprises, and the science and technology competition projects, promoted "special topic type" and "project type" teaching; in the recent three years, there have been above 550 projects and competitions in classroom per year.

Promote the application of modernized education technology. The school has constructed "course center" and other platforms, above 100 shared courses, 38 resource sharing courses, and successively introduced above 20 of network courses, and the annual average quantity of registered students can reach to above 3,000. "Mooc", "Flipped Classroom", "Micro-lesson" and the reform of other online and offline combined teaching mode and method reform are still developing.

2) Implement "hundred-industry teacher cultivation" plan, and create "double-teacher and double-capacity type" teacher team

The school has formulated (revised) the Management Methods for Young Teachers to Go to Enterprises, Title Review Regulations, Post Appointment Regulations, guided young teachers to go to enterprises for above 3 months of exercise, and encouraged teachers to obtain the registered qualification certificate of relevant industry; currently, the proportion of "double-teacher and double-capacity" teachers can reach to above $36 \%$; through adopting the mode of closely docking with the industry and setting technical research institute (institution, center), industry (domain) cooperation alliance and other modes, extensively carry out applied scientific research; in the recent three years, the proportion of applied scientific research for teachers can reach to above $80 \%$, and the quantity of students annually participating in the scientific research of teachers can teach to 1,200 , the rate for graduation thesis of students from the first practice line can reach to $70 \%$, the guidance rate of teachers for the science and technology contest, innovation and entrepreneurship, and entrepreneurship guidance of teachers can reach to $100 \%$, and the right application quantity for students is about 200 .

3) Optimize governance structure, and construct "schoolenterprise interest community"

The school is set with the board of directors that can closely dock with the industry and enterprises, adopts "three-service" as the orientation to conduct the transformation of on-campus service institution and procedures, promote university and college two-level administration and personnel distribution system reform; through school-enterprise talent cultivation alliance, industrial colleges, school-enterprise cooperation class, industry-university-research base and other modes, create various forms of "interest community", gradually form five types of cooperation, including "scientific research service promotion type", explore and accumulate various routes and long-term governance mechanism of school-enterprise integration and industry-university combination.

\section{MAIN INNOVATION OF TEACHING REFORM}

(1)The school has put forward the teaching service college positioning with distinct characteristics, and explored a complete set of applied talent cultivation mechanism. The project group has carried out a systematic and comprehensive research on the teaching service universities, published lots of high-level thesis, and also well guided the teaching reform and practice. The school takes three-service demand of "regional economy, employment market, innovation and entrepreneurship" as the orientation, and through the reform of "specialties, courses, and practice", it has realized the docking of industry (domain) and post group, conducted "course innovation, applied teachers, and governance structure" and other three matching reforms, and constantly deepened applied talent cultivation.

(2)The school has innovatively put forward and implemented three types of applied talent cultivation positioning, including, "composite type, field type and occupational type". Through taking "discipline-industryoccupation" as the research view, the school has divided the applied talent cultivation into three basic types from professional direction and occupational perspective, and meanwhile, refined the cultivation objective and specification, etc., conducted successful practice and exploration, and enriched the relevant theory of applied talent cultivation.

(3)The school has explored five types of new mechanism for school-enterprise cooperation. Through school-enterprise talent cultivation alliance, industrial college, school-enterprise cooperation class, industry-university-research base and other modes, the school has created "intermediary linkage type", "scientific research service promotion type", "internship employment combination type", "internship linkage type", "industrial expert employment type" and other "interest communities", and constructed school-enterprise cooperation long-term valid mechanism. 


\section{INITIAL EFFECT}

The school has cultivated a batch of excellent applied talents. Since 2009 when it implemented 3 specialty pilots, it has constantly expanded the reform range, and then in 2010, it newly increased 8 pilot specialties, and up till present, it has radiated the reform practice of all undergraduate specialties, and above 400 teachers have participated in the reform; the quantity of directly benefited students can reach to above 4,300, and the quantity of indirectly benefited students can reach to above 20,000. Currently, the reform has constructed 1 national characteristic specialty, 1 provincial advantage specialty, 4 provincial emerging characteristic specialties, and partial projects, such as service outsourcing, steel structure, international service trade and other talent cultivation modes have highlighted characteristics.

The reform implementation has vigorously promoted the students' enthusiasm and employment competition. Through implementing "excellent classroom", "innovative classroom" and other activity plans, the students' learning enthusiasm is largely improved, and the "class attendance rate" and "attention" have been improved to $95.3 \%$ and $96.97 \%$ from original $89 \%$. The employment rate of students is obviously increased, and according to 2013 Annual Report of Social Demand and Cultivation Quality of MyCOS for our school, 2009 Grade employment competition index for civil engineering, social work and three reform pilot specialties of the achievement was above $90 \%$ averagely, the specialty fitting rate reached to $73 \%$, the non-employment rate after half a year reached to $97.3 \%$ averagely, which was $2 \%$ higher than the provincial common undergraduate colleges, and the average monthly incomes for six months after graduation was respectively RMB 2,920, 2,945 and 2,689, which were $20 \%$ higher than that of last term averagely. The annual employment rate of the school was stabilized at above $95 \%$. In the recent three years, the total award winning quantity of students in scientific and technical competition of the school reached to above 50 second awards per year, which was increased by above $20 \%$ than before.

The school has formed a batch of theoretical and practical research achievements, obtained high recognition of the government and bigger response among similar colleges nationwide. The project group published above 30 theses through Education Research, Education Development Research and Chinese Higher Education Research and other journals and academic journals, Zhejiang Daily, Zhejiang Education Journal and other news media have also reported the applied talent cultivation, and course reform practice in our school; as the Provincial Secretary, Comrade Xia Baolong, has specially given instructions about the professional housekeeping talent cultivation alliance; the project presenter has made special report for above 80 universities nationwide upon invitation; the members of the project group have successively conducted experience introduction at "Total Provincial University Course Textbook Seminar", "Chinese and Foreign Private Education Teaching Reform Seminar", National Newly Built Undergraduate University Alliance Conference and other total provincial conferences. Above 60 brother universities, including Hunan University of Humanities, Science and Technology, Heilongjiang Oriental College, Changshu Institute of Technology, Taizhou University, and Jiangxi University of Technology successively came to our school for communication and experience. At the end of 2015, the school was selected as "the Applied Pilot Construction Demonstration University in Zhejiang Province", and its successful experience has good reference meaning for the transformation of newly built undergraduate universities.

\section{CONCLUSION}

The application transformation of newly built undergraduate universities is a long-term and arduous task, which not only requires various universities to conduct active exploration in practice, but also requires the competent department of the government to energetically provide guidance and support. Zhejiang Shuren University takes the construction of "teaching service type universities" as the objective, and the construction of industrial universities as the main emphasis, and over the years, it has conducted certain exploration and practice for applied type talent cultivation, obtained periodic achievements and it still requires further reform and practices

\section{ACKNOWLEDGMENT}

About the Author: Jin Jinbiao (October, 1969- ), professor, born in Yiwu, Zhejiang, the Section Chief for Scientific Research Department of Zhejiang Shuren University, and the main research direction is: higher education management, and educational law.

\section{REFERENCES}

[1] Xu Xuqing, Teaching Service Type University: Theoretical Research and System Framework [M], China Social Sciences Press 2014 Version, Introduction.

[2] Wu Zhongjiang and Huang Chengliang. Applied Talent Connotation and Applied Undergraduate Talent Cultivation [J]. Researches in Higher Education of Engineering, 2014 (2). 